\title{
Deconstructing Gravity: Trade Costs and Extensive and Intensive Margins
}

\author{
Martina Lawless *0 \\ Central Bank and Financial Services Authority of Ireland
}

\begin{abstract}
This paper uses data on US exports to decompose exports into the number of exporting firms (the extensive margin) and average export sales (the intensive margin). We show how a range of proxies for trade costs has different impacts on the two margins. Distance has a negative effect on both margins, but the magnitude is considerably larger for the extensive margin. Most of the variables capturing language, internal geography, infrastructure and import cost barriers work through the extensive margin. We show that these results are consistent with a Melitz-style model of trade with heterogeneous firm productivity and fixed costs.
\end{abstract}




\section{Introduction}

One of the longest-standing and most robust empirical results in international economics is the existence of a negative relationship between aggregate exports and distance. This relationship is usually estimated as part of a gravity equation for trade, a log-linear specification linking trade flows to the GDP of trading partners and the geographical distance between them. ${ }^{1}$ More recent research on exporting activity at the firm level has established an apparently equally robust result - few firms export, and exporting firms usually sell in a limited number of markets. ${ }^{2}$ This has led to the development of new models of trade that focus on firm-level exporting decisions. The most influential of these has been Melitz's (2003) model, which is based on assumptions of firm heterogeneity in productivity and fixed costs. This combination implies the existence of a productivity threshold for each country that firms must exceed if they are to export to that country.

An important implication of the threshold-productivity prediction is that it results in both an extensive (number of firms) and intensive (average exports per firm) margin to total trade. The extensive margin exists because firms that cannot export enough to cover their fixed costs will not export at all. This contrasts with the predictions of popular models used to generate the gravity relationship, such as Anderson and van Wincoop (2003), which assume homogeneous firms within each country and consumer love of variety ensures that all goods are traded everywhere. There is no extensive margin in these models and all adjustment to changes in trade costs should therefore occur on the intensive margin.

This paper uses data from the US Census Bureau, detailing exports and numbers of exporting firms from the US to 156 destination markets, to decompose total exports into number of firms and average export sales per firm. We use this decomposition to show how GDP as well as distance and a range of other proxies for trade costs have different impacts on both the extensive and intensive margins. Regressions of the sort discussed in this paper were recently reported by Bernard, Jensen, Redding and Schott (2007). This paper goes beyond their analysis in two important respects.

First, Bernard, Jensen, Redding and Schott used this decomposition into extensive and intensive margins to examine only the effects of GDP and distance. However, the literature on gravity models has identified a large number of proxies for trade costs in addition to distance. This paper thus extends the extensive and intensive margin regressions by adding variables such as common language, influences of internal geography, and infrastructure. 
In addition, we use new data from the World Bank on the costs associated with importing procedures (Djankov, Freund and Pham, 2010). These include financial costs coming from customs and port fees as well as less tangible costs such as the length of time it takes for imports to be processed and the complexity of the importing procedure, measured by the number of documents that have to be completed for each container-load.

Second, we show how these results can be interpreted in the context of a standard heterogeneous firms model of exporting. In particular, we use a simplified version of the Melitz (2003) model to show how various factors will affect the two margins. The Melitz model predicts that the extensive margin is negatively affected by both fixed and variable trade costs. There is no such clear prediction for the intensive margin however. For example, an increase in variable costs will reduce the sales of all firms exporting to a given country, but may also result in some of the lowest sales firms exiting the market, thus resulting in an ambiguous effect for average sales per firm. In addition, the model predicts that sales per firm should be positively related to fixed trade costs. Thus, the model predicts that variables such as GDP, which might be expected to be correlated with fixed trade costs, should have a positive effect on sales per firm, while those variables that impact on variable trade costs should have a clear effect on the extensive margin (number of firms), and perhaps have little effect on the intensive margin (sales per firm).

The results from our analysis largely confirm the model's prediction. We find that most of the variables used in our analysis affect exports largely through their influence on the extensive margin. Distance has a negative effect on both margins, but the magnitude of the coefficient is considerably larger for the extensive margin. All of the variables capturing language, internal geography, and import cost barriers have significant and appropriately signed effects on the extensive margin. However, almost none of these variables are found to have a statistically significant relationship with the intensive margin. The results show that the only factor to consistently affect the intensive margin is the size of the market.

The remainder of the paper is organised as follows. Section 2 presents a simple model of exporting with heterogeneous firms and fixed costs and discusses the model's implications for the intensive and extensive margins. Section 3 discusses the data. Section 4 presents the results for the basic and augmented gravity model. Section 5 concludes. 


\section{Model with Heterogeneous Firms and Fixed Trade Costs}

In this section, a simple version of the model first presented by Melitz (2003) and adapted by Chaney (2008) is presented and the expressions this generates for the number of exporters and average exports in each destination are highlighted. The different ways that these latter expressions depend upon trade costs and GDP are discussed. The key features of the model are that firms are heterogeneous in their productivity and face both fixed and variable costs in order to export. The model begins with a general formulation of the productivity distribution and then show the results are affected when the distribution is assumed to be Pareto. The Melitz structure has often been used to model bilateral trade flows across a range of sectors and countries. However, as the data used later in the paper are for exports from a single country, we will describe a model with firms from a single exporting country and therefore we suppress the home country subscript to simplify the notation.

\subsection{Assumptions and Productivity Threshold}

Assume that each country produces a continuum of separate differentiated products, and that consumers in the foreign country $j$ have a utility function across the goods $k$ produced in all countries that takes the form

$$
U_{j}=\left[\int x_{j}(k)^{\frac{\epsilon-1}{\epsilon}} d k\right]^{\frac{\epsilon}{\epsilon-1}}
$$

Thus, the demand for good $k$ in country $j$ is

$$
x_{j}(k)=\frac{p_{j}(k)^{-\epsilon} Y_{j}}{P_{j}^{1-\epsilon}}
$$

where $p_{j}(k)$ is the price charged in country $j$ for good $k, Y_{j}$ is real income in country $j$ and $P_{j}$ is the Dixit-Stiglitz price level defined by

$$
P_{j}=\left[\int p_{j}(k)^{1-\epsilon} d k\right]^{\frac{1}{1-\epsilon}}
$$

It is assumed that the exporting country produces a continuum of separate differentiated products of unit mass. Each firm produces a single product according to a Ricardian technology with cost-minimizing unit cost $\frac{c}{a}$, where $c$ relates to the exporting country's 
cost level and $a$ is the firm-specific productivity parameter. The productivity parameter $a$ is assumed to be randomly drawn from a distribution $G(a)$ with probability density function on the support $[0, \infty]$.

There are two types of trade costs associated with exporting to country $j$. First, there are fixed costs $F_{j}$. These can be viewed as related to bureaucratic paperwork costs associated with exporting, to marketing costs, and to the costs of running a wholesale and retail distribution chain. It is likely that each of these costs increase with the scale of exports; however, it is also likely that many of these costs need to be incurred independent of the scale of subsequent export sales. Second, there are variable costs, which are modeled with the iceberg specification so that $\tau_{j}$ units have to be shipped from our country of interest to country $j$ for one unit to arrive. These can be viewed as transport costs, tariffs, and the variable costs associated with marketing and distribution.

The assumptions about market structure and trade costs imply that the optimal selling price to country $j$ for a good produced with technology level $a$ is

$$
p_{j}(a)=\frac{\epsilon}{\epsilon-1} \frac{\tau_{j} c}{a}
$$

This implies profits generated by this product in country $j$ are given by

$$
\pi_{j}(a)=\mu\left(\frac{P_{j} a}{\tau_{j} c}\right)^{\epsilon-1} Y_{j}-F_{j}
$$

where $\mu=(\epsilon-1)^{\epsilon-1} \epsilon^{-\epsilon}$. Thus, profits generated by exporting this product to country $j$ are positive as long as

$$
a>\left(\frac{F_{j}}{\mu Y_{j}}\right)^{\frac{1}{\epsilon-1}} \frac{\tau_{j} c}{P_{j}}
$$

This defines a cut-off level of productivity necessary for entry into country $j$ as

$$
\bar{a}_{j}=\left(\frac{F_{j}}{\mu Y_{j}}\right)^{\frac{1}{\epsilon-1}} \frac{\tau_{j} c}{P_{j}}
$$

so that only firms with productivity above this level will sell in country $j$. As would be expected, this cut-off level of productivity is increasing in both types of trade costs and in domestic cost levels, while it is negatively affected by export country GDP and the price level in country $j$. 


\subsection{Intensive and Extensive Margins of Trade}

To calculate the model's predictions for the intensive and extensive margins, we begin with the expression for the exports of firm $i$ to country $j$, which are

$$
s_{i j}=p_{i j} x_{i j}=\left(\frac{P_{j}}{p_{i j}}\right)^{\epsilon-1} Y_{j}
$$

Inserting the formula for the optimal price, this gives us

$$
s_{i j}=\left(\frac{\epsilon-1}{\epsilon} \frac{P_{j} a_{i}}{\tau_{j} c}\right)^{\epsilon-1} Y_{j}
$$

Thus, sales of an individual good depend positively on productivity, on the export country's GDP and price level, and negatively on variable trade costs. Once the firm has become an exporter, fixed costs do not have any impact on the level of sales. Total sales to country $j$ are obtained by integrating across all productivity levels above the cut-off level for participation $\bar{a}$ :

$$
S_{j}=\int_{\bar{a}_{j}}^{\infty} s_{j}(a) G(a)
$$

The change in total exports due to a change in any type of trade costs, $x$ is given by:

$$
\frac{\partial S_{j}}{\partial x}=\int_{\bar{a}_{j}}^{\infty} \frac{\partial s_{j}(a)}{\partial x} G(a) d a-s_{j}\left(\bar{a}_{j}\right) G\left(\bar{a}_{j}\right) \frac{\partial \bar{a}_{j}}{\partial x}
$$

Total exports to $j$ are affected by a change in trade costs through two channels - the first part of the expression is the change in sales of firms already above the productivity threshold and the second part gives the change in the threshold itself. An increase in variable trade costs affects both parts of the expression, by reducing the sales of current exporters and also by increasing the productivity level needed to export. Fixed costs do not affect the sales of current exporters but will still impact total sales as it is included in determining the threshold productivity, an increase in which may result in some firms exiting the market.

The number of firms exporting to each market is derived using the formula for the productivity cut-off:

$$
N_{j}=\int_{\bar{a}_{j}}^{\infty} G(a) d a
$$

The change in the number of firms due to a change in trade costs, $x$ is given by

$$
\frac{\partial N_{j}}{\partial x}=-G\left(\bar{a}_{j}\right) \frac{\partial \bar{a}_{j}}{\partial x}
$$


This shows the negative relationship between trade costs and number of exporters. As increases in trade costs shift upward the threshold level of productivity needed to export, fewer firms are above the bar and the number of exporters falls.

Finally, the expressions for total exports and number of exporters can be combined to give the average exports per firm:

$$
\frac{S_{j}}{N_{j}}=\frac{\int_{\bar{a}_{j}}^{\infty} s_{j}(a) G(a) d a}{\int_{\bar{a}_{j}}^{\infty} G(a) d a}
$$

Average exports are affected by trade costs according to:

$$
\frac{\partial\left(\frac{S_{j}}{N_{j}}\right)}{\partial x}=\frac{\frac{\partial S_{j}}{\partial x} N_{j}-S_{j} \frac{\partial N_{j}}{\partial x}}{N_{j}^{2}}
$$

The total change in the intensive margin depends on how the change in trade costs affects both total sales and the number of firms. Fixed and variable trade costs have quite different effects on average sales. In the case of a change in fixed costs, the effect is unambiguous. An increase in $F_{j}$ will not affect the sales of continuing exporters, so from equation (11), we get

$$
\frac{\partial S_{j}}{\partial F_{j}}=-s_{j}\left(\bar{a}_{j}\right) G\left(\bar{a}_{j}\right) \frac{\partial \bar{a}_{j}}{\partial F_{j}}
$$

Inserting this and the expression for $\frac{\partial N_{j}}{\partial F_{j}}$ (following 13) into the expression implied by equation (15) and we get

$$
\begin{aligned}
\frac{\partial\left(\frac{S_{j}}{N_{j}}\right)}{\partial F_{j}} & =\frac{-s_{j}\left(\bar{a}_{j}\right) N_{j} G\left(\bar{a}_{j}\right) \frac{\partial \bar{a}_{j}}{\partial F_{j}}+S_{j} G\left(\bar{a}_{j}\right) \frac{\partial \bar{a}_{j}}{\partial F_{j}}}{N_{j}^{2}} \\
& =\frac{\left(S_{j}-s_{j}\left(\bar{a}_{j}\right) N_{j}\right) G\left(\bar{a}_{j}\right) \frac{\partial \bar{a}_{j}}{\partial F_{j}}}{N_{j}^{2}}
\end{aligned}
$$

Because $S_{j}-s_{j}\left(\bar{a}_{j}\right) N_{j}>0$ (total sales are greater than if all firms sold the same as the threshold firm), $G\left(\bar{a}_{j}\right)>0$ (continuous distribution) and $\frac{\partial \bar{a}_{j}}{\partial F_{j}}>0$ (higher fixed costs raise the threshold), the effect of fixed costs on sales per firm can be signed as positive. By increasing the productivity threshold required to export, the increase in $F_{j}$ eliminates lowsales firms while keeping high-sales firms and this raises the average sales per firm.

In the case of an increase in variable trade costs, there is also an increase in the productivity threshold for exporting (in the same way as fixed costs), removing some marginal 
exporters from the market. However, variable costs also have an effect on the exports of firms that remain in the market. The expression for the effect of a change in variable costs on average exports is given by

$$
\begin{aligned}
\frac{\partial\left(\frac{S_{j}}{N_{j}}\right)}{\partial \tau_{j}} & =\frac{\left(\int_{\bar{a}_{j}}^{\infty} \frac{\partial s_{j}(a)}{\partial \tau_{j}} G(a) d a-s_{j}\left(\bar{a}_{j}\right) G\left(\bar{a}_{j}\right) \frac{\partial \bar{a}_{j}}{\partial \tau_{j}}\right) N_{j}+S_{j} G\left(\bar{a}_{j}\right) \frac{\partial \bar{a}_{j}}{\partial \tau_{j}}}{N_{j}^{2}} \\
& =\frac{\left(\int_{\bar{a}_{j}}^{\infty} \frac{\partial s_{j}(a)}{\partial \tau_{j}} G(a) d a\right) N_{j}+\left(S_{j}-s_{j}\left(\bar{a}_{j}\right) N_{j}\right) G\left(\bar{a}_{j}\right) \frac{\partial \bar{a}_{j}}{\partial \tau_{j}}}{N_{j}^{2}}
\end{aligned}
$$

The first term in the numerator of this expression is the change in export sales of existing exporters as a result of a change in variable trade costs, and this term is negative. The second term relates to the raising of the threshold bar (it is identical in form to the expression for fixed trade costs) and thus is positive. Without additional assumptions about the form of the productivity distribution, $G(a)$, the overall effect cannot be signed, leaving us with an ambiguous effect of $\tau$ on average sales. The same expression can also be derived for changes in export market GDP. This raises the sales of all continuing firms but also introduces marginal low-sales firms. Note, though, that higher GDP may also contribute to raising the fixed costs associated with exporting to that market, so this may offset the threshold-bar effect and contribute to a positive effect.

The predictions of the model can be summarized as follows.

- The number of firms exporting to a market should depend positively on the market's GDP and negatively on factors that affect the fixed and variable trade costs associated with the market.

- The model has more ambiguous predictions for sales per firm. Factors that reduce variable trade costs tend to increase sales of existing firms but reductions in fixed and variable trade costs also allow more marginal producers into the market, thus implying an ambiguous effect on sales per firms for a range of variables expected to impact upon trade costs.

- Export market GDP has an ambiguous direct effect on sales per firm as it raises total exports but also induces the entry of smaller firms. 


\subsection{Pareto Productivity Distribution Example}

Before moving on to our empirical analysis, we think it is worth pointing out that more definite predictions for the impact of variable trade costs on sales per firm can be derived if more specific assumptions are made about the form of heterogeneity in productivity. Specifically, the model produces clean analytical results if, following Helpman, Melitz and Yeaple (2004) and Chaney (2008), one assumes that the productivity parameter $a$ is randomly drawn from a Pareto distribution with probability density function $G(a)=\gamma a^{-\gamma-1}$ on the support $[1, \infty]$ (meaning $c$ has the interpretation of the cost of the minimum-productivity technology). Beyond analytical convenience, there is empirical evidence that important firm-level distributions, such as for firm size, follow a Pareto distribution. ${ }^{3}$ In addition, Gabaix (1999) has shown that Pareto distributions can be generated from an aggregation of random micro-level exponential growth shocks to each of the individual units, while Kortum (1997) has shown that the upper tail of productivity distributions needs to be Pareto if steady-state growth paths are to be sustained.

As before, the extensive margin is given by integrating above the productivity cut-off point, giving the expression:

$$
N_{j}=\int_{\bar{a}_{j}}^{\infty} G(a) d a=\bar{a}_{j}^{-\gamma}=\left(\frac{P_{j}}{\tau_{j} c}\right)^{\gamma}\left(\frac{\mu Y_{j}}{F_{j}}\right)^{\frac{\gamma}{\epsilon-1}}
$$

The number of firms is increasing in the GDP and price level of the destination market and is negatively related to both fixed and variable trade costs.

Total export sales to country $j$ are now given by:

$$
\begin{aligned}
S_{j} & =\left(\frac{\epsilon-1}{\epsilon} \frac{P_{j}}{\tau_{j} c}\right)^{\epsilon-1} Y_{j} \int_{\bar{a}_{j}}^{\infty} a^{\epsilon-1} G(a) d a \\
& =\frac{\gamma}{\gamma-\epsilon+1}\left(\frac{\epsilon-1}{\epsilon} \frac{P_{j}}{\tau_{j} c}\right)^{\epsilon-1} Y_{j} \bar{a}_{j}^{\epsilon-\gamma-1}
\end{aligned}
$$

Again we note that once it has been decided that a product will be exported, its subsequent sales are independent of the fixed cost but that variable costs have a negative impact. ${ }^{4}$ The average value of exports per product can now be calculated directly as

$$
\frac{S_{j}}{N_{j}}=\frac{\gamma}{\gamma-\epsilon+1}\left(\frac{\epsilon-1}{\epsilon} \frac{P_{j}}{\tau_{j} c}\right)^{\epsilon-1} Y_{j} \bar{a}_{j}^{\epsilon-1}
$$

This can be simplified by inserting the formula for the cutoff value of productivity from equation (7). In this case, all of the terms involving $Y_{j}, P_{j}, \tau_{j}$ and $c$ cancel out, leaving the 
formula:

$$
\frac{S_{j}}{N_{j}}=\frac{\gamma \epsilon}{\gamma-\epsilon+1} F_{j}
$$

We obtain a prediction that sales per firm are directly proportional to fixed trade costs but do not depend at all on the effect of variable trade costs or foreign market GDP. We have shown already that an increase in $\tau_{j}$ reduces the exports of all firms that choose to continue to sell to market $j$ but also eliminates some marginal low-sales firms from the market. These calculations show that when productivity is drawn from a Pareto distribution, these two counteracting forces exactly offset each other.

This example shows that for a reasonable calibration of the productivity distribution, it is possible for some variables to have significant effects on the number of firms exporting to a market but to have no effect on sales per firm in that market.

\subsection{Alternative Definitions and Extensions}

\subsubsection{Definitions of Intensive and Extensive Margins}

The definitions used in this paper for the extensive and intensive margins of trade, relating to numbers of firms and export sales per firm, have previously been used by Eaton, Kortum and Kramarz (2004) and Eaton, Eslava, Kugler and Tybout (2008). These definitions also broadly follow the three-fold decomposition of Bernard, Jensen, Redding and Schott (2007), who use firm-product data to distinguish between two extensive margins for exporting firms (i.e. the number of products that firms trade and the number of export destinations) and an intensive margin (i.e. the value they trade per product per country). However, for complete clarity, we should note that the related literature has also used two other definitions of these margins.

Firstly, our definitions of these margins differ from those discussed by Chaney (2008) and estimated by Crozet and Koenig (2010). The definition used in both of these papers of the extensive margin relates to the sales of the marginal exporter and not to average sales across all exporters. This provides a useful theoretical decomposition of the effects of changes in exogenous parameters. It has the disadvantage, however, of being based on a thought experiment: How much would firms that have exited sell if they were still exporting, or how much would firms that have just arrived have sold if they were exporting last period? Crozet and Koenig (2010) use French data on exporting firms to estimate the structural parameters derived by Chaney, namely the effect of the elasticity of substitution, elasticity 
of trade costs to distance and the degree of firm heterogeneity in different industries. ${ }^{5}$ They find the estimated parameters are consistent in sign and size with the Chaney model for a majority of sectors.

Secondly, our definition of these margins differs from that used in papers based on aggregate bilateral trade data such as Baldwin and Harrigan (2007) and Helpman, Melitz and Rubinstein (2008). These papers focus on the fact that some countries do not trade with each other at all and then analyse the extensive margin as relating to whether countries trade and the intensive margin as relating to total bilateral export sales if they do trade. In focusing on the one-zero nature of whether we observe any trade data between countries, this approach misses the more general importance of an extensive margin such that numbers of firms participating in export markets tend to decline relatively rapidly as one moves away from the most popular markets. This has been documented both by Bernard, Jensen, Redding and Schott (2007) for the US and by Eaton, Kortum and Kramarz (2004) for France. ${ }^{6}$

\subsubsection{Multiproduct Firms}

We define the extensive margin as the number of firms exporting to an individual destination country. In doing so, we are implicitly assuming that each firm produces a single product. In a more realistic framework of multiproduct firms, there would also exist withinfirm margins related to how many of its products would be exported to each market and the average exports across products. Evidence on this within-firm margin is presented in Bernard, Jensen, Redding and Schott (2007). Although the available data does not contain information on the number of products produced, it is useful to briefly discuss how the existence of multiproduct firms might affect the expected results.

The Melitz model approach is consistent with a range of current models of multiproduct firms. Models such those of Bernard, Redding and Schott (2006) and Eckel and Neary (2010) assume that firms have range of different potential productivities across the products they can make. Bernard, Redding and Schott assume a multiplicative approach in which a firm's efficiency in making an individual product is determined by a firm-specific value times a random value drawn for that specific product. Eckel and Neary instead assume that each firm attains its maximum productivity for a particular "core" product and that its efficiency gradually declines as one moves away from this product according to a defined space for differentiated products. In either of these models, whether a firm chooses to 
make a particular product at all will depend upon whether its productivity draw for that product exceeds one of the thresholds that exist for all markets, including the home market. Similarly, whether a firm chooses to export a product to market $j$ will depend upon whether its productivity draw for that product exceeds $\bar{a}_{j}$. Firms will thus choose to sell more products in markets with low productivity thresholds. A firm with no product over the threshold for market $j$ will not export there at all.

\section{Data}

We use data from 2006 on the number of US firms and their average export sales to each destination market. These data come from the US Census Bureau's "Profile of U.S. Exporting Companies" (US Census Bureau, 2008). The data is based on detailed export documentation used to compile the official U.S. trade statistics. The number of destinations used in this analysis is limited to 156 countries due to availability of data on explanatory variables. Table 1 shows the known value of exports ${ }^{7}$ and number of exporting firms to the top 25 foreign markets as published by the Census Bureau. The largest destination is Canada with over 87,000 firms from the US exporting there; the number of firms exporting to each market decreases rapidly, with half of the number of firms exporting to Mexico (the next most popular destination for US exports) as to Canada. The $25^{t h}$-largest market, Saudi Arabia, has less than one-tenth of the number of exporters as Canada.

The explanatory variables at the country level come from a number of sources and are listed in Table 2. The standard gravity variables of destination GDP (in US dollars) comes from the World Bank's World Development Indicators database and distance between capital cities comes from Jon Haveman's website.

Data on administrative costs of international trade come from the Doing Business Survey, undertaken by the World Bank in 2005 (for a detailed description see Djankov, Freund and Pham, 2010). The costs detailed in this dataset relate to customs inspections, storage and handling at the port and documentation required in the importing country. The costs are compiled on the basis of a homogeneous import good; specifically, the cost is that of processing a dry-cargo, 20-foot container requiring no special treatment such as refrigeration or environmental safety standards. Three variables are used to capture the administrative costs of trade: The first is the number of documents that must be filled to import the container into the country, the second is the average length of time in days it 
takes for all the technical and customs procedures to be completed and the third is the cost of all the fees associated with customs clearance and handling at the port (but does not include taxes or tariffs). The importance of time delays in trading and the associated costs of storage and depreciation (particularly of time-sensitive products such as fresh produce) has been examined by Hummels (2001), who estimated that each day saved in transporting manufactured goods is worth 0.8 percent ad-valorem.

Ability to communicate in a common language is predicted to reduce the costs of trade. We use a dummy variable representing English as a common language if it is (one of the) official language(s) in the destination market, also from the Haveman website. To capture effects of internal geography and level of development, we use a number of infrastructural and access variables from World Bank World Development Indicators. In terms of communications infrastructure, access to information on the market can make it easier for a firm to investigate the market and to conduct business (Anderson and van Wincoop, 2004). We use the extent of telephone and computer usage to proxy for the ease of information gathering and running a business abroad.

To augment the market size variable, we use two additional measures to capture how easily the exporting firm can gain access to this market. The physical size of the country (area in square kilometres) is used to proxy for internal transportation costs. The population density is also used as an indicator of internal geography that might make it easier for the exporter to reach a large proportion of the market without having to set up a very large distribution network.

\section{Gravity Model of Intensive and Extensive Margins}

This section presents the results of an econometric gravity model for total trade, separating the effects of explanatory variables into those relating to the number of firms exporting and those relating to average exports per firm. The first subsection uses a simple variance decomposition to illustrate the relative contributions of the intensive and extensive margins to variations in total exports. The second subsection describes the empirical specification and the results of the basic gravity formulation using market size and distance. The third subsection then augments the model by adding further variables that may influence the costs of exporting, such as common language, infrastructure indicators and bureaucracy measures. 


\subsection{Variance Decomposition}

The variation in total exports to different markets can be decomposed into the contributions of variation in the number of firms, the average exports per firm and a term related to the covariance of these two elements.

$$
\operatorname{Var}\left(\ln S_{j}\right)=\operatorname{Var}\left(\ln N_{j}\right)+\operatorname{Var}\left(\ln \frac{S_{j}}{N_{j}}\right)+2 \operatorname{Cov}\left(\ln N_{j}, \ln \frac{S_{j}}{N_{j}}\right)
$$

We find that the variation in number of firms contributes over half $(0.52)$ of the total variation in exports, variation in average export sales contributes 0.14 to the total and the remaining 0.34 is due to the covariance between the two terms. As $\frac{S_{j}}{N_{j}}$ in the Pareto distribution case depends only on $F$, the high covariance is compatible with the model if one assumes that fixed trade costs are positively correlated with the GDP of the destination market. This seems reasonable as one might expect that larger markets require firms to operate on a larger scale or that higher fixed costs could result from more expensive marketing costs and costs of running a wholesale and retail distribution chain. On the other hand richer countries tend to have better infrastructure and lower regulatory burdens and these advantages may be more important for fixed trade costs. In a similar vein, Krautheim (2008) finds evidence that network effects endogenously lower costs of entry in larger markets as the number of firms exporting there increases. The empirical results presented in the rest of this section show support for the positive correlation of GDP with fixed costs, while at the same time being consistent with improvements in infrastructure working to lower fixed costs.

\subsection{Empirical Specification and Benchmark Results}

As in Bernard, Jensen, Redding and Schott (2007), the aggregate export sales $S$ to country $j$ are decomposed into the number of firms exporting to the destination, $N_{j}$ and the average exports per firm $S / N$. This decomposition can be expressed in log form as:

$$
\ln S_{j}=\ln N_{j}+\ln \frac{S_{j}}{N_{j}}
$$

Each of the three components (total exports, number of firms and average exports) are regressed on a range of variables that might be expected to have an effect on the costs of trading internationally:

$$
\ln Z_{j}=\alpha+\beta \ln D_{j}+\gamma \ln G D P_{j}+\delta X_{j}+\epsilon_{j}
$$


where $Z$ represents either total sales, number of exporters or average exports per firm, $D$ is bilateral distance, GDP is gross domestic product in the destination market and $X$ is a range of other factors proxying for trade costs. The gravity model generally includes both importer and exporter income as explanatory variables: however, as we use data on exporting from a single source country, its income level will be picked up in the regression constant. As is standard in the gravity literature, all the variables are expressed in logs, allowing us to interpret the coefficients as elasticities. Using OLS means that the coefficients on number of firms and average sales per firm will sum to give the coefficient on total exports.

The benchmark gravity model, using just GDP and distance as explanatory variables, is presented in Table 3. The results for total exports show, as expected, a significant negative relationship between trade and distance and a significant positive coefficient on destination GDP. The distance coefficient on total trade is -1.32 . This is slightly higher than the average distance elasticity of -0.9 found by Disdier and Head (2008) in a meta-analysis of 103 gravity model papers. They found that $90 \%$ of estimates were between -0.28 and -1.55 , so our result is well within the standard range.

Splitting the total trade into the number of firms and average exports shows that most of the distance effect is working through inhibiting entry: The coefficient on the extensive margin is -1.06, approximately four-fifths of the total effect. The effect on average exports is also negative but is considerably smaller. Interpreting this result (and those on the trade costs in the next subsection) in terms of the theoretical predictions depends on whether we regard the trade cost proxies we use as primarily capturing variable or fixed costs. In practice, many trade costs are likely to have both fixed and variable elements to them. In the case of distance, the usual assumption in the gravity framework is that it reflects transportation costs, which vary with the amount exported. However, there may be fixed cost elements to transportation (such as loading and unloading at ports) that are not proportional to the distance traveled. In addition, distance may capture costs other than distance - Krautheim (2009) shows informational networks in foreign markets decline with distance and the absence of these networks increase the costs of market entry. The coefficients for the effect of distance on the extensive and intensive margin in the data used here seem most consistent with distance operating as a proxy for variable costs. The negative coefficient for the effect of distance on the intensive margin is consistent only with the general model's result of ambiguous effects on sales per firm - if the Pareto assumption was to hold, we 
would expect the variable cost effects to offset one another perfectly and any fixed cost element of distance to have a positive relationship with average sales.

The decomposition of the GDP effect is somewhat more equal across the two margins than the distance effect, but it still works mainly through the extensive margin: The total effect of 0.94 is made up of a coefficient of 0.65 on the extensive margin and 0.29 on the intensive margin. As noted above, the positive effect of GDP on sales per firm may reflect its effect on fixed trade costs. Regarding the fit of the model, a feature of all our specifications is that the $R^{2}$ is always higher, sometimes considerably so, for number of firms compared to the $R^{2}$ for average exports. In the benchmark case, the $R^{2}$ for number of firms is 0.77 and for average sales per firm it is 0.56 . Again this is consistent with the theoretical framework, which suggests systematic relationships across countries between numbers of firms and the range of explanatory variables but implies more ambiguous and possibly weak relationships for average sales per firm.

This benchmark regression can be compared to the results of Bernard et al. (2007) who use a sample of 175 countries for the year 2000. As one would expect, the results are almost identical. They report a total effect for GDP of 0.98 comprising an extensive margin effect of 0.71 and an intensive margin effect of 0.27 . Their distance effect was 1.36 for total exports, divided into an effect of -1.14 for the extensive margin and -0.22 for the intensive margin. ${ }^{8}$ The slight variation in the coefficients is most likely to be due to sampling differences, e.g. their data refer to 2000 rather than 2006.

\subsection{Infrastructure Variables and Costs of Trade}

This section augments the gravity model by including additional variables that might be expected to affect the costs of trading internationally. Supplementing the distance proxy for costs of getting to the country, we now add costs incurred at the border. The Doing Business Survey, conducted by the World Bank, provides the measures for costs of import processing in the destination country, both financial and in terms of the burden of paperwork and time. As the measures are all relatively highly correlated, they are entered into the specification separately, the results of which are presented in Table 4. The administrative complexity of the importing process, as measured by the number of documents that need to be completed, is negatively associated with total trade and with the number of firms exporting to the market. The length of time required to fulfill all the necessary requirements has a similar effect. Finally, the total financial cost of import restrictions, also has a negative 
impact on total trade and the number of exporters, and is the variable associated with the highest $R^{2}$ for the number of firms. None of these trade cost measures have any discernible impact on average sales. As all of these costs are constructed as relating to the importation of a single container, they are clear candidates for consideration as variable costs. The significant effect only on the extensive margin is consistent with this interpretation.

Table 5 adds measures of common language and communications infrastructure to the basic gravity specification. The dummy variable for English as an official language is positively related to total trade. Again, we find that this effect works entirely through the extensive margin, with the coefficient on the English dummy having a statistically insignificant effect on the intensive margin.

Also included in Table 5 are results using measures of the extent of telephone and internet networks as indicators both of the ease of transacting business for firms in the market and also for accessing information prior to an entry decision. Both of the measures have positive and significant effects on total trade, with the number of fixed and mobile telephones per hundred people performing somewhat better in terms of model fit. Both telephone and internet networks have a positive relationship with the number of firms. Perhaps surprisingly, however, phone and internet coverage have a negative impact on average exports per firm. This result suggests that good phone and internet networks might be best interpreted as variables that reduce fixed trade costs - by making it easier for firms to export, they may be associated with lower average sales per firm.

The distance coefficient captures the costs of transportation to the foreign market. Further costs of transportation are likely to be incurred within the country and Table 6 presents results for two proxies for internal geography that may influence these costs. The first is the physical area of the country, which should increase the costs of supplying that market and, as one would expect, it has a negative coefficient on total trade. This is not a perfect measure of course, as population is rarely evenly distributed within a country. For this reason, we also add a measure of population density (people per square kilometre). Markets where consumers are relatively highly concentrated may be more accessible for exporters with lower transportation costs and possibly also lower costs for marketing and administration in general. Population density indeed has a positive effect on total exports. Again, the division of the effects of these internal geography measures shows that both work entirely through the extensive margin of trade. The area and density measures have no significant effect on the intensive margin. 
Drawing all of the elements together, Table 7 presents results for an extended gravity model that includes a range of trade cost variables in addition to the standard elements of GDP and distance. The results remain comparable to the specifications in which the costs are entered separately, with statistically significant coefficients in the regression for the number of firms and not in the regression for average exports per firm. The exception is the measure of the telephone network, which again has a negative and significant coefficient in the average exports regression. The fit of this extended model is higher than that the benchmark model that contained just GDP and distance. The $R^{2}$ for the total trade column has increased slightly from 0.82 to 0.85 . The extra trade cost variables do particularly well in explaining the variation in the number of firms; the $R^{2}$ of the extended model is 0.84 compared to 0.77 for the benchmark. On the other hand, there is very little improvement in the fit of the average firm exports regression (0.58 in the extended model compared to 0.56 in the benchmark). The lack of improvement in fit and the generally insignificant coefficients for the average exports regressions are consistent with the predictions of the model, because the impact of trade costs were shown to have an ambiguous effect on this intensive margin.

A range of alternative specifications were used to examine the robustness of the results presented in this paper. ${ }^{9}$ The inclusion of OECD or regional dummies have almost no qualitative effect on the results. Dividing the sample into OECD and non-OECD destinations shows the results are robust for the non-OECD sample but the very small sample size for the OECD group resulted in several of the measures becoming insignificant; the exceptions were the standard GDP and distance results, as well as area and density measures. The overall pattern of results was also robust to the use of population weights in the OLS regression, with the communications cost variables the only group to drop their significance level.

\section{Conclusions}

The gravity model relating trade flows to GDP and proxies for trade costs is one of the most empirically successful in international economics. This paper decomposes the gravity model into an extensive (number of firms) and intensive (average export sales per firm) margin. We begin by using a simplified version of the Melitz (2003) model of firm exportswhich incorporates firm heterogeneity in productivity and fixed trade costs for each export 
market - to generate predictions for how trade costs should impact on the two margins of trade. The model gives a clear prediction that the extensive margin is negatively affected by both fixed and variable trade costs, but the prediction for the intensive margin contains counteracting terms whose overall sign is unclear. Lowering trade costs tend to raise the sales of continuing exporters but also leads to the introduction of new more marginal exporters with lower average sales.

We then apply the gravity model specification to the extensive and intensive margins in US exports across 156 countries, examining the effect of a range of variables commonly shown to impact on the cost of exporting. In addition to the standard gravity variables of size and distance, we add factors such as common language, internal geography and communications infrastructure. Furthermore, we use new data from the World Bank on the costs associated with importing procedures, including both financial costs coming from customs and port fees, the length of time it takes for imports to be processed and the complexity of the importing procedure.

The results strongly confirm the predictions of the Melitz theoretical framework and run counter to popular models of the gravity relationship, such as Anderson and van Wincoop (2003), which feature homogeneous firms and no extensive margin. Most of the variables relating to trade costs affect US exports only through their influence on the extensive margin. In addition, regressions for the extensive margin have a much better fit than those for the intensive margins. Of all the variables used, only those reflecting the size of the market and some proxies for communications infrastructure had a robustly significant effect on the intensive margin, with these variables having negative effects. And to the extent that these communications networks can reduce the fixed costs associated with trade, these results are also consistent with the Meltiz model. 


\section{References}

[1] Anderson, James and Eric van Wincoop (2003) 'Gravity with Gravitas: A Solution to the Border Puzzle,' in American Economic Review, 93, 170-92

[2] Anderson, James and Eric van Wincoop (2004) 'Trade Costs,' in Journal of Economic Literature, 42, 691-751

[3] Axtell, Robert (2001) 'Zipf Distribution of US Firm Sizes,' in Science, 7 September $2001,1818-1820$

[4] Baldwin, Richard and James Harrigan (2007) 'Zeros, Quality and Space: Trade Theory and Trade Evidence', NBER Working Paper 13214

[5] Bernard, Andrew and J. Bradford Jensen (1995) 'Exporters, Jobs and Wages in US Manufacturing: 1976-1987' in Brookings Papers on Economic Activity: Microeconomics, $67-112$

[6] Bernard, Andrew and J. Bradford Jensen (2004) 'Why Do Some Firms Export?' in Review of Economics and Statistics, 86, 561-569

[7] Bernard, Andrew, J. Bradford Jensen, Stephen Redding, and Peter Schott (2007) 'Firms in International Trade,' in Journal of Economic Perspectives, Vol 21, Summer, $105-130$

[8] Bernard, Andrew, Stephen Redding, and Peter Schott (2006) 'Multiproduct Firms and Trade Liberalization,' mimeo, Dartmouth

[9] Chaney, Thomas (2008) 'Distorted Gravity: The Intensive and Extensive Margins of International Trade', in American Economic Review, Vol. 98, No. 4, 1707-1721

[10] Crozet, Matthieu and Pamina Koenig (2010) 'Structural gravity equations with intensive and extensive margins,' in Canadian Journal of Economics, 43(1), forthcoming

[11] Disdier, Anne-Celia and Keith Head (2008) 'The Puzzling Persistence of the Distance Effect on Trade,' in Review of Economics and Statistics, 90, 3748

[12] Djankov, Simeon, Caroline Freund and Cong S. Pham (2010) 'Trading on Time', in Review of Economics and Statistics, Vol.92, No.1, 166-173 
[13] Eaton, Jonathan, Marcela Eslava, Maurice Kugler and James Tybout (2008) 'The Margins of Entry into Export Markets: Evidence from Columbia,' in The Organization of Firms in a Global Economy, ed. Elhanan Helpman, Dalia Marin and Thiery Verdier (Cambridge MA: Harvard University Press)

[14] Eaton, Jonathan, Samuel Kortum and Francis Kramarz (2004) 'Dissecting Trade: Firms, Industries and Export Destinations,' in American Economic Review Vol. 94, No.2, 150-152

[15] Eckel, Carsten and J. Peter Neary (2010) 'Multi-Product Firms and Flexible Manufacturing in the Global Economy,' in Review of Economic Studies, 77:1, 188-217

[16] Gabaix, Xavier (1999) 'Zipf's Law for Cities: An Explanation,' in Quarterly Journal of Economics, Vol.114, No.3, 739-67

[17] Helpman, Elhanen, Marc Melitz, and Stephen Yeaple (2004) 'Export versus FDI with Heterogeneous Firms,' in American Economic Review, Vol. 94, 300-316

[18] Helpman, Elhanan, Marc Melitz and Yona Rubinstein (2008) 'Estimating Trade Flows: Trading Partners and Trading Volumes,' in Quarterly Journal of Economics, 123, 441487

[19] Hummels, David (2001) 'Time as a Trade Barrier', Purdue University, mimeo

[20] Hummels, David and and Peter Klenow (2005) 'The Variety and Quality of a Nation's Exports,' in American Economic Review, 95, 704-723

[21] Isard, Walter (1954) 'Location Theory and Trade Theory: A Short-Run Analysis,' in Quarterly Journal of Economics, Vol. 68, No.2, 305-320

[22] Kortum, Samuel (1997) 'Research, Patenting and Technological Change,' in Econometrica Vol.65, No.6, 1389-1419

[23] Krautheim, Sebastian (2009) 'Gravity and Information: Heterogeneous Firms, Exporter Networks and the 'Distance Puzzle", mimeo, Paris School of Economics

[24] Lawless, Martina (2009) 'Firm Export Dynamics and the Geography of Trade,' in Journal of International Economics, Volume 77, No.2, 245-254 
[25] Melitz, Marc (2003) 'The Impact of Trade on Intra-Industry Reallocations and Aggregate Industry Productivity,' in Econometrica Vol. 71, No.6, 1695-1725

[26] US Census Bureau (2008). Profile of U.S. Exporting Companies (Washington: US Department of Commerce) 


\section{Notes}

${ }^{0}$ Thanks to Kristen Corwin and Benjamin Shelak at the US Census Bureau for making unpublished data from the "Profile of U.S. Exporting Companies" available to me. The views expressed in this paper are the author's own, and do not necessarily reflect the views of the Central Bank and Financial Services Authority of Ireland or the ESCB. Contact details: Economic Analysis and Research Department, Central Bank and Financial Services Authority of Ireland, PO Box 559, Dame Street, Dublin 2, Ireland. E-mail: martina.lawless@centralbank.ie. Telephone:+353 12246303.

${ }^{1}$ The gravity relationship for trade dates back at least as far as Isard (1954) and has been estimated econometrically many times over the years. See Disdier and Head (2008) for a useful summary.

${ }^{2}$ See for instance, Bernard and Jensen (1995, 2004), Eaton, Kortum and Kramarz (2004), Bernard, Jensen, Redding and Schott (2007), and Lawless (2009).

${ }^{3}$ See Axtell (2001) for evidence on size distributions of US firms.

${ }^{4}$ Note from this last calculation that it is necessary to assume $\gamma>\epsilon-1$. Higher values for $\gamma$ implies that the distribution of productivity levels falls off faster. If this parameter is assumed to be too small, then firms with high productivity (and thus high sales) would become so important that the integral for total sales would not converge to a finite value.

${ }^{5}$ Crozet and Koenig also include a discussion of the definitions of extensive and intensive margins as they are used in this paper when they describe their data, but the main focus of their empirical estimation is based on the Chaney definitions.

${ }^{6} \mathrm{~A}$ third approach, used by Hummels and Klenow (2005), defines the extensive margin as the number of products exported by a country, and the intensive margin is the average sales per product.

${ }^{7}$ Only data on exports that could be linked to firms is used, thereby slightly understating the total exports to any individual destination but giving a more accurate figure for average export sales.

${ }^{8}$ Bernard et al. actually report three margins as they divide the intensive margin into 
two components - the number of products per firm and the average sales per product. I have combined the coefficients of these two components to compare like with like, as the data used in this paper does not contain product information.

${ }^{9}$ These are available as an online technical appendix. 
Table 1: Exports and Exporting Firms to Top 25 Markets

\begin{tabular}{|l|r|r|}
\hline \hline & $\begin{array}{r}\text { Exports } \\
(\$ \text { millions })\end{array}$ & $\begin{array}{r}\text { Number } \\
\text { of Firms }\end{array}$ \\
\hline Canada & 178,507 & 87,554 \\
Mexico & 118,174 & 44,204 \\
Japan & 55,984 & 26,648 \\
China & 51,902 & 25,873 \\
United Kingdom & 40,861 & 39,684 \\
Germany & 37,722 & 29,416 \\
South Korea & 29,657 & 19,184 \\
Netherlands & 29,293 & 16,370 \\
Singapore & 22,584 & 18,278 \\
France & 22,463 & 17,674 \\
Taiwan* & 21,610 & 16,754 \\
Belgium & 20,158 & 10,635 \\
Brazil & 18,024 & 13,465 \\
Australia & 15,578 & 24,553 \\
Hong Kong & 16,139 & 21,765 \\
Switzerland & 12,965 & 10,195 \\
Italy & 11,487 & 17,344 \\
Malaysia & 11,987 & 9,479 \\
United Arab Emirates & 11,169 & 11,055 \\
Israel & 8,003 & 12,806 \\
India & 9,404 & 13,774 \\
Venezuela & 8,346 & 9,200 \\
Ireland & 7,933 & 7,882 \\
Thailand & 9,775 \\
\hline Saudi Arabia & 7,709 \\
\hline
\end{tabular}

* Not included in this paper's analysis due to a lack of data on explanatory variables 
Table 2: Variable Definitions and Sources

\begin{tabular}{|c|c|c|}
\hline Variable & Definition & Source \\
\hline Distance & $\begin{array}{l}\text { Distance in kilometres } \\
\text { from Washington DC to } \\
\text { destination's capital city }\end{array}$ & $\begin{array}{l}\text { Jon Haveman International } \\
\text { Trade Data website }{ }^{a}\end{array}$ \\
\hline GDP & $\begin{array}{l}\text { Gross Domestic Product } \\
\text { in US dollars }\end{array}$ & $\begin{array}{l}\text { World Bank } \\
\text { World Development Indicators (WDI) }\end{array}$ \\
\hline English & $\begin{array}{l}\text { Dummy variable }=1 \text { if } \\
\text { English is an official language }\end{array}$ & $\begin{array}{l}\text { Jon Haveman International } \\
\text { Trade Data website }\end{array}$ \\
\hline Phones & $\begin{array}{l}\text { Fixed line and mobile phone } \\
\text { subscribers (per } 100 \text { people) }\end{array}$ & World Bank WDI \\
\hline Internet & $\begin{array}{l}\text { Internet users } \\
\text { (per } 100 \text { people) }\end{array}$ & World Bank WDI \\
\hline Area & $\begin{array}{l}\text { Surface area } \\
\text { in square kilometres }\end{array}$ & World Bank WDI \\
\hline Density & $\begin{array}{l}\text { Population per } \mathrm{km}^{2} \\
\text { (Data for } 2005)\end{array}$ & $\begin{array}{l}\text { United Nations } \\
\text { World Population Prospects }\end{array}$ \\
\hline Documents & $\begin{array}{l}\text { Number of documents required } \\
\text { to process imports at port of entry }\end{array}$ & Doing Business Survey \\
\hline Time & $\begin{array}{l}\text { Number of days taken to } \\
\text { process imports at port of entry }\end{array}$ & Doing Business Survey \\
\hline Costs & $\begin{array}{l}\text { Cost in US dollars of all fees } \\
\text { and charges at port of entry } \\
\text { (excluding tariffs) }\end{array}$ & Doing Business Survey \\
\hline
\end{tabular}


Table 3: Benchmark Gravity Model

\begin{tabular}{|l|ccc|}
\hline \hline & \multicolumn{3}{|c|}{ Dependent Variable } \\
& Ln Total Exports & Ln Number of Firms & Ln Average Firm Exports \\
\hline Ln Distance & $-1.32^{* * *}$ & $-1.06^{* * *}$ & $-0.26^{* * *}$ \\
& $(0.17)$ & $(0.14)$ & $(0.08)$ \\
Ln GDP & $0.94^{* * *}$ & $0.65^{* * *}$ & $0.29^{* * *}$ \\
& $(0.04)$ & $(0.03)$ & $(0.02)$ \\
$R^{2}$ & & & 0.56 \\
Observations & 0.82 & 0.77 & 156 \\
\hline
\end{tabular}

Notes: Robust standard errors in parentheses.

$* * *$ indicates significance at $1 \%$ level, ${ }^{* *}$ at $5 \%$ and $*$ at $10 \%$. 
Table 4: Procedures and Costs of Trade

\begin{tabular}{|c|c|c|c|c|c|c|c|c|c|}
\hline & \multicolumn{9}{|c|}{ Dependent Variable } \\
\hline & $\begin{array}{l}\text { Ln Total } \\
\text { Exports }\end{array}$ & $\begin{array}{l}\text { Ln Number } \\
\text { of Firms }\end{array}$ & $\begin{array}{c}\text { Ln Average } \\
\text { Firm Exports }\end{array}$ & $\begin{array}{l}\text { Ln Total } \\
\text { Exports }\end{array}$ & $\begin{array}{l}\text { Ln Number } \\
\text { of Firms }\end{array}$ & $\begin{array}{c}\text { Ln Average } \\
\text { Firm Exports }\end{array}$ & $\begin{array}{l}\text { Ln Total } \\
\text { Exports }\end{array}$ & $\begin{array}{l}\text { Ln Number } \\
\text { of Firms }\end{array}$ & $\begin{array}{c}\text { Ln Average } \\
\text { Firm Exports }\end{array}$ \\
\hline Ln Distance & $\begin{array}{c}-1.24^{* * *} \\
(0.18)\end{array}$ & $\begin{array}{c}-0.96^{* * *} \\
(0.14)\end{array}$ & $\begin{array}{c}-0.27^{* * *} \\
(0.08)\end{array}$ & $\begin{array}{c}-1.24^{* * *} \\
(0.17)\end{array}$ & $\begin{array}{c}-0.96^{* * *} \\
(0.13)\end{array}$ & $\begin{array}{c}-0.28^{* * *} \\
(0.08)\end{array}$ & $\begin{array}{c}-1.32^{* * *} \\
(0.15)\end{array}$ & $\begin{array}{c}-1.07^{* * *} \\
(0.12)\end{array}$ & $\begin{array}{c}-0.25^{* * *} \\
(0.08)\end{array}$ \\
\hline Ln GDP & $\begin{array}{c}0.92^{* * *} \\
(0.04)\end{array}$ & $\begin{array}{c}0.62^{* * *} \\
(0.03)\end{array}$ & $\begin{array}{c}0.30^{* * *} \\
(0.02)\end{array}$ & $\begin{array}{c}0.89^{* * *} \\
(0.04)\end{array}$ & $\begin{array}{c}0.58^{* * *} \\
(0.03)\end{array}$ & $\begin{array}{c}0.31^{* * *} \\
(0.02)\end{array}$ & $\begin{array}{c}0.90^{* * *} \\
(0.04)\end{array}$ & $\begin{array}{c}0.60^{* * *} \\
(0.03)\end{array}$ & $\begin{array}{c}0.30^{* * *} \\
(0.02)\end{array}$ \\
\hline Ln Import Docs & $\begin{array}{c}-0.67^{* *} \\
(0.30)\end{array}$ & $\begin{array}{c}-0.82^{* * *} \\
(0.23)\end{array}$ & $\begin{array}{c}0.16 \\
(0.15)\end{array}$ & & & & & & \\
\hline Ln Import Time & & & & $\begin{array}{c}-0.46^{* *} \\
(0.18)\end{array}$ & $\begin{array}{c}-0.61^{* * *} \\
(0.14)\end{array}$ & $\begin{array}{c}0.15 \\
(0.10)\end{array}$ & & & \\
\hline Ln Import Cost & & & & & & & $\begin{array}{c}-0.80^{* * *} \\
(0.18)\end{array}$ & $\begin{array}{c}-0.86^{* * *} \\
(0.12)\end{array}$ & $\begin{array}{c}0.06 \\
(0.11)\end{array}$ \\
\hline$R^{2}$ & 0.83 & 0.78 & 0.56 & 0.83 & 0.80 & 0.56 & 0.84 & 0.82 & 0.56 \\
\hline Observations & 156 & 156 & 156 & 156 & 156 & 156 & 156 & 156 & 156 \\
\hline
\end{tabular}


Table 5: Language and Communications Infrastructure

\begin{tabular}{|c|c|c|c|c|c|c|c|c|c|}
\hline & \multicolumn{9}{|c|}{ Dependent Variable } \\
\hline & $\begin{array}{l}\text { Ln Total } \\
\text { Exports }\end{array}$ & $\begin{array}{l}\text { Ln Number } \\
\text { of Firms }\end{array}$ & $\begin{array}{c}\text { Ln Average } \\
\text { Firm Exports }\end{array}$ & $\begin{array}{l}\text { Ln Total } \\
\text { Exports }\end{array}$ & $\begin{array}{l}\text { Ln Number } \\
\text { of Firms }\end{array}$ & $\begin{array}{c}\text { Ln Average } \\
\text { Firm Exports }\end{array}$ & $\begin{array}{l}\text { Ln Total } \\
\text { Exports }\end{array}$ & $\begin{array}{l}\text { Ln Number } \\
\text { of Firms }\end{array}$ & $\begin{array}{c}\text { Ln Average } \\
\text { Firm Exports }\end{array}$ \\
\hline Ln Distance & $\begin{array}{c}-1.34^{* * *} \\
(0.18)\end{array}$ & $\begin{array}{c}-1.09^{* * *} \\
(0.15)\end{array}$ & $\begin{array}{c}-0.25^{* * *} \\
(0.08)\end{array}$ & $\begin{array}{c}-1.19^{* * *} \\
(0.18)\end{array}$ & $\begin{array}{c}-0.85^{* * *} \\
(0.13)\end{array}$ & $\begin{array}{c}-0.34^{* * *} \\
(0.08)\end{array}$ & $\begin{array}{c}-1.25^{* * *} \\
(0.18)\end{array}$ & $\begin{array}{c}-0.91^{* * *} \\
(0.14)\end{array}$ & $\begin{array}{c}-0.34^{* * *} \\
(0.08)\end{array}$ \\
\hline Ln GDP & $\begin{array}{c}0.96^{* * *} \\
(0.04)\end{array}$ & $\begin{array}{c}0.67^{* * *} \\
(0.03)\end{array}$ & $\begin{array}{c}0.29^{* * *} \\
(0.02)\end{array}$ & $\begin{array}{c}0.88^{* * *} \\
(0.04)\end{array}$ & $\begin{array}{c}0.55^{* * *} \\
(0.03)\end{array}$ & $\begin{array}{c}0.33^{* * *} \\
(0.02)\end{array}$ & $\begin{array}{c}0.91^{* * *} \\
(0.04)\end{array}$ & $\begin{array}{c}0.58^{* * *} \\
(0.03)\end{array}$ & $\begin{array}{c}0.33^{* * *} \\
(0.02)\end{array}$ \\
\hline English Dummy & $\begin{array}{l}0.48^{* *} \\
(0.20)\end{array}$ & $\begin{array}{c}0.57^{* * *} \\
(0.18)\end{array}$ & $\begin{array}{l}-0.09 \\
(0.11)\end{array}$ & & & & & & \\
\hline Ln Phones & & & & $\begin{array}{l}0.22^{* *} \\
(0.09)\end{array}$ & $\begin{array}{c}0.36^{* * *} \\
(0.07)\end{array}$ & $\begin{array}{c}-0.14^{* *} \\
(0.05)\end{array}$ & & & \\
\hline Ln Internet & & & & & & & $\begin{array}{c}0.11 \\
(0.09)\end{array}$ & $\begin{array}{c}0.26^{* * *} \\
(0.06)\end{array}$ & $\begin{array}{c}-0.15^{* * *} \\
(0.05)\end{array}$ \\
\hline$R^{2}$ & 0.83 & 0.78 & 0.56 & 0.83 & 0.80 & 0.57 & 0.82 & 0.79 & 0.58 \\
\hline Observations & 156 & 156 & 156 & 156 & 156 & 156 & 156 & 156 & 156 \\
\hline
\end{tabular}

Notes: Robust standard errors in parentheses. ${ }^{* * *}$ indicates significance at $1 \%$ level, ${ }^{* *}$ at $5 \%$ and ${ }^{*}$ at $10 \%$. 
Table 6: Accessibility

\begin{tabular}{|c|c|c|c|c|c|c|}
\hline & \multicolumn{6}{|c|}{ Dependent Variable } \\
\hline & $\begin{array}{l}\text { Ln Total } \\
\text { Exports }\end{array}$ & $\begin{array}{l}\text { Ln Number } \\
\text { of Firms }\end{array}$ & $\begin{array}{l}\text { Ln Average } \\
\text { Firm Exports }\end{array}$ & $\begin{array}{l}\text { Ln Total } \\
\text { Exports }\end{array}$ & $\begin{array}{l}\text { Ln Number } \\
\text { of Firms }\end{array}$ & $\begin{array}{l}\text { Ln Average } \\
\text { Firm Exports }\end{array}$ \\
\hline Ln Distance & $\begin{array}{c}-0.27^{* * *} \\
(0.17)\end{array}$ & $\begin{array}{c}-1.00^{* * *} \\
(0.12)\end{array}$ & $\begin{array}{c}-0.27^{* * *} \\
(0.08)\end{array}$ & $\begin{array}{c}-1.35^{* * *} \\
(0.16)\end{array}$ & $\begin{array}{c}-0.109^{* * *} \\
(0.13)\end{array}$ & $\begin{array}{c}-0.25^{* * *} \\
(0.08)\end{array}$ \\
\hline Ln GDP & $\begin{array}{c}1.02^{* * *} \\
(0.05)\end{array}$ & $\begin{array}{c}0.75^{* * *} \\
(0.03)\end{array}$ & $\begin{array}{c}0.27^{* * *} \\
(0.03)\end{array}$ & $\begin{array}{c}0.93^{* * *} \\
(0.04)\end{array}$ & $\begin{array}{c}0.64^{* * *} \\
(0.03)\end{array}$ & $\begin{array}{c}0.29^{* * *} \\
(0.02)\end{array}$ \\
\hline Ln Area & $\begin{array}{c}-0.13^{* *} \\
(0.05)\end{array}$ & $\begin{array}{c}-0.17^{* * *} \\
(0.04)\end{array}$ & $\begin{array}{c}0.03 \\
(0.03)\end{array}$ & & & \\
\hline $\begin{array}{l}\text { Ln Population } \\
\text { Density }\end{array}$ & & & & $\begin{array}{l}0.14^{*} \\
(0.08)\end{array}$ & $\begin{array}{l}0.16^{* *} \\
(0.06)\end{array}$ & $\begin{array}{l}-0.01 \\
(0.04)\end{array}$ \\
\hline$R^{2}$ & 0.83 & 0.79 & 0.56 & 0.83 & 0.78 & 0.56 \\
\hline Observations & 156 & 156 & 156 & 156 & 156 & 156 \\
\hline
\end{tabular}

Notes: Robust standard errors in parentheses. ${ }^{* * *}$ indicates significance at $1 \%$ level, ${ }^{* *}$ at $5 \%$ and $*$ at $10 \%$. 
Table 7: Extended Gravity Model

\begin{tabular}{|c|c|c|c|}
\hline & \multicolumn{3}{|c|}{ Dependent Variable } \\
\hline & Ln Total Exports & Ln Number of Firms & Ln Average Firm Exports \\
\hline \multirow[t]{2}{*}{ Ln Distance } & $-1.36^{* * *}$ & $-1.01^{* * *}$ & $-0.35^{* * *}$ \\
\hline & $(0.16)$ & $(0.11)$ & $(0.07)$ \\
\hline \multirow[t]{2}{*}{ Ln GDP } & $0.89^{* * *}$ & $0.53^{* * *}$ & $0.36^{* * *}$ \\
\hline & $(0.10)$ & $(0.06)$ & $(0.08)$ \\
\hline \multirow[t]{2}{*}{ English Dummy } & $0.50^{* * *}$ & $0.58^{* * *}$ & -0.08 \\
\hline & $(0.18)$ & $(0.15)$ & $(0.12)$ \\
\hline \multirow[t]{2}{*}{ Ln Phone } & 0.05 & $0.24^{* *}$ & $-0.19^{*}$ \\
\hline & $(0.16)$ & $(0.09)$ & $(0.11)$ \\
\hline \multirow[t]{2}{*}{ Ln Density } & 0.10 & $0.14^{* *}$ & -0.04 \\
\hline & $(0.12)$ & $(0.07)$ & $(0.09)$ \\
\hline \multirow[t]{2}{*}{ Ln Area } & 0.04 & 0.07 & -0.04 \\
\hline & $(0.11)$ & $(0.07)$ & $(0.09)$ \\
\hline \multirow[t]{2}{*}{ Ln Cost } & $-0.76^{* * *}$ & $-0.72^{* * *}$ & -0.04 \\
\hline & $(0.18)$ & $(0.11)$ & $(0.12)$ \\
\hline$R^{2}$ & 0.85 & 0.84 & 0.58 \\
\hline Observations & 156 & 156 & 156 \\
\hline
\end{tabular}

Notes: Robust standard errors in parentheses.

*** indicates significance at $1 \%$ level, ${ }^{* *}$ at $5 \%$ and $*$ at $10 \%$. 